北滿松花江站附近發見の遺物

奥田值榮

1937年、私は V. V. Ponosov 等に、第二松花江南岸松花江驛附近 (西方) から先 史時代遺物が發見されると閆いた。而して翌年夏數日間同地の發掘を試みた。今回の 調䄳は時、天候に惠まれ秋して學術的であつたとは云へをい。層位の觀察等に於い ては失败に近かつた。其上、渡滿後日淺く先學の過去業績すらも充分に把握して居な レのである。從つて報文には心が進まぬ。然し乍ら、未開拓地での發見のニニースは、 迅速を旨とす可をであらう。又 A. S. LoukASHKIN は、自身探集標本を集んで提供 され發表を您渠せられたのである。で不取敢、當院所藏品の一部を圖示し小文を副へ 以て豫報の責を塞ぎたん。

土器 完形品はなかつたが、多量破片が主に表面探集でではあるが獲られた。此等 が相互間に如何なる年代的、文化的關係にあるのか現在の私には殆ど論求する事が出 來をいが、特に注目を惹いた點を二三述べよう。

先づ有紋品が相當あるのに氣付く。第 1 圖 1 は、屈折した沈線と其下方に尖端で答 刺した㥞な點紋あるもの、2，3 は短沈線分の 2 本或は 3 本が平行して 1 組をなすもの を配して居る。4は器の属折部で、貼附したらしく見える浮紋上に圖の樣て溝があ る。此漵と浮紋の配合は、5の例等と或は密接な關係を持つのかも知れぬ。か」る手 法は、V. V. Ponosov 探集品等を見ると、2本の垂下する線束を 1 部で短い横線束 で縛つた樣な感を谌へる $\mathrm{H}$ (又は $\mathrm{X}$ ) 字狀の紋㥞（５も斯種に屬すか？）とも連絡 するらしく思はれる。6は、鄖拊けをと見える浮紋上に刻目ある 1 例、7は口緗部 で、口唇より約 $2 \mathrm{~cm}$ 下方から横走する粘土細帶を段にして附してある。內壁に條線 ある外表面から開穿した 1 孔がある。 8,10 のものと同㥞外表面に於ける徑は內表面 での夫より大きい。9は寫嶽に判然せぬが横走の欮があり、其相互間に短線分が横に 連らねられたものでロ縁部らしい。11は口縁部破片で、斷面三角形の横隆起帶上に割 に深く大きい刻目がならぶ。12 は口唇が外反し一種の刻目縁を示す。口唇部の形態 


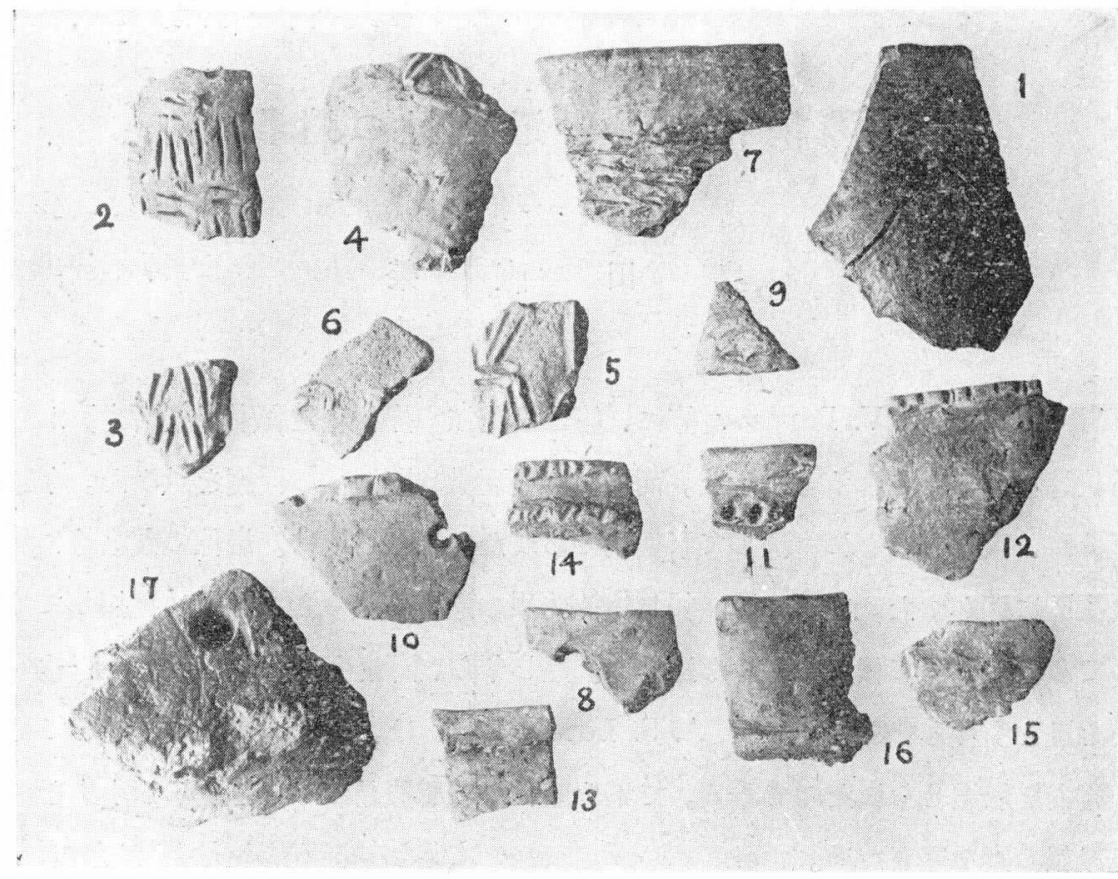

第 1 圆

は種々ある。13 は無紋だが口唇が外表面に著しく垂下した例。14 は口唇部の外表面 に降起帶が出來、下方の橫隆起帶と同樣な刻日がある。横隆帶のある破片も少くなく 15,16 乙無紋乍ら其奶例。以上のものは黄褐色、赤褐色、黑褐色等在呈する。3，13, 15 等に特に著しいのだが、主に白色を帶びる稍角稜を持つ小不粘が混じて居る物もあ る。此種の小粒を含子上述の他間之略同似した土質、色調を持つ底部破片には、丸形 平底で縱斷面の外壁が外曲するものが普通らしい。17がそれで、外底面から穿つた條 線ある 1 孔が第れて居るが、てれは貫通して居ない。

次に上述品の多くとは一見して制別し得る土質の仰間がある。細砂粒を含有し、外 表面は赤褐色、赤橙色を呈し、魔研した痕跡があると思へるものも多い。(此赤色の表面 を持つ破片の破摧部を檢すると、黑、青灰色等を帶びる心層が筧取される埸合が少くな い。水洗で甚しく脫落する樣な事もないが、燒成時の條件によるのでなく蜜ろ故意に 赤く塗附けたものだと云ふ感を抱せる標本がある。殆ぞ無紋と云つてよい。而して第 2 圖中に代表例を示した所謂鬲形土器脚部殘片、把手や圖示しをいが若干探取した口 底部に反りの殆皆與の口緣部破片等の䓕だ多數が之に編入されるのは與味深い。第2 


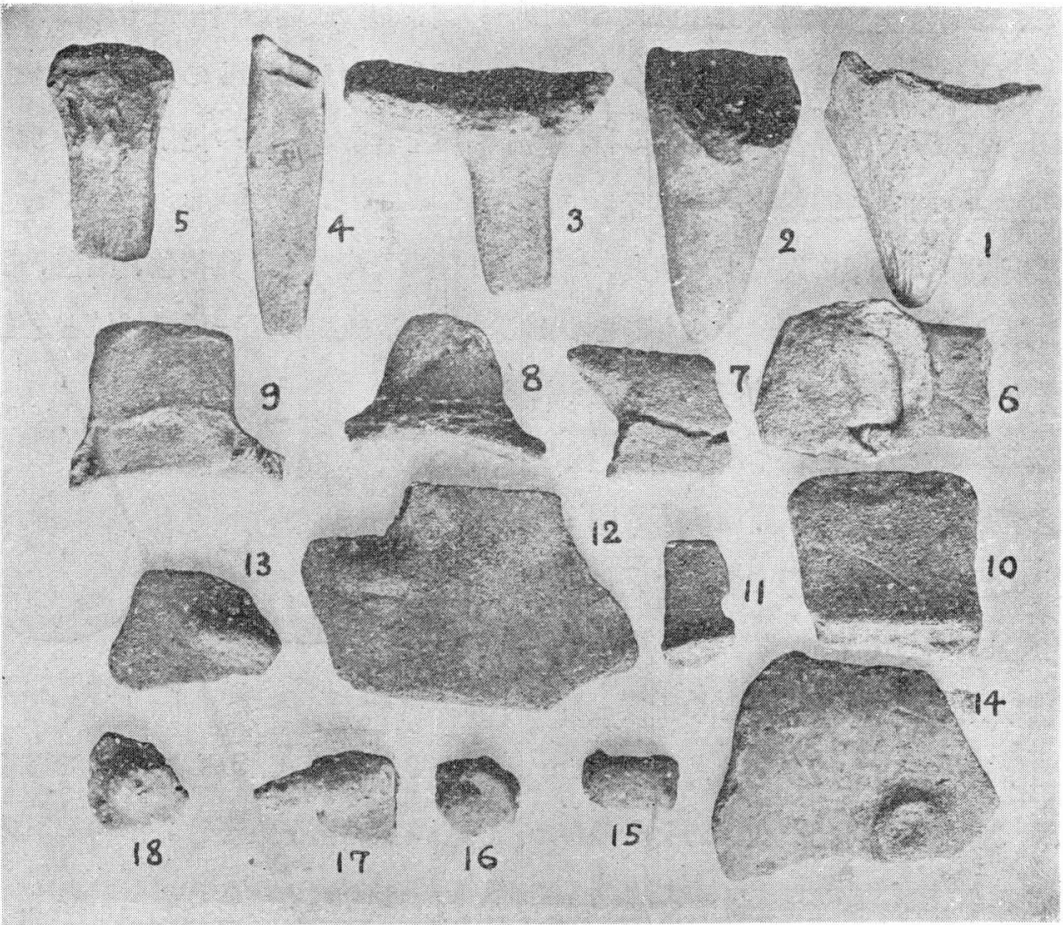

第 2 圖

圖 1,2 は所謂鬲形土器腿部。2 2 、比較的脚端が尖がるもので、內底面の落込みの 底は 1 の樣に平坦でない。1は、脚端が殺がれを樣になり其本坦面を我平に置くと體 軸は稍斜倒する。外表面には一見繩紋樣の物が施されて居る。下述の橋狀把手でもさ らであるが、前記した帶白色小粒を含み土質は餘り細砂粘を持を和寧ろ第 1 圖中の\& のに近いとさへ思へる仰間が若干ある。此脚部と次の二者媳橋狀把手、柱狀物は、何 十個と稱せる程多產した。3,4,5 は断面四角形の柱狀物だが、原器での正確な部位は

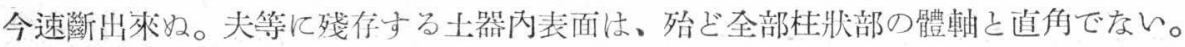
そして 5 の如く基部に棒狀の器具で突刺した樣な痕跡ある例が存する。先端は平坦な のが普通らしい。6,7 は憍状把手。6 は稟面で製作時の過程を物語る。裝着方向は詳 でない。8，9，10 は器壁から棚狀に突出する把手。8 は上面觀、先端が猍ばまるもの、 10 は廣がる例 (先端幅約 $5.4 \mathrm{~cm}$ ) である。11は有孔の同類品破片であらう。

$12,13,14$ 女細砂粒を含夕帶赤色表面を倠するから、第 2 圖中上述のものの大部分 と同樣に取扳へるかっも知れぬ。何れも撮みが附着する。12のは小形橋狀把手を押潰し 
た樣で、13のは小形の棚爿營起に入るらしい仲間、14のは圓形扁平なものである。而 して 12,14 の柡な類には細砂粒を多く含まない質を持つた 15,16 の如をものもある。 尤も16注切株状で稍異る。17は例の帶白色小石粘を含むが一種の把手であららか。18 も白色粒を含份する圓錐师の小形撮みである。

他に所謂陶質土器に入る土質精良、燒成良好堅緻で青灰色、黄褐色、黑色、橙色等 を呈し敲けば金屬性の響がするものを少からず得た。紋㥞には一種の繩紋と之を磨消 するやらにした横走線(帶)等が多く見られる。

土製紡鍾車所謂紡鏵車なるものの你するの は注意すべきであらう。斷面は第 3 圖 1 は紡鍾 形( ?)飞近く、2 は山形である。共に黄褐色を 帶び中軸に貫孔がある。2の方が幾分光澤があ り形彇飞整ふ。石器と同樣どの土器と件出する

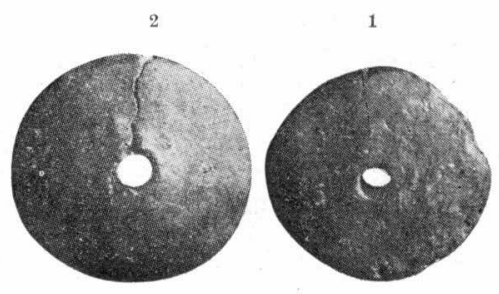

第 3 圖 のか速斷乙得故い。最厚部は共に $1.5 \mathrm{~cm}$ 前後、2の直徑は $5.8 \mathrm{~cm}$ 程度である。

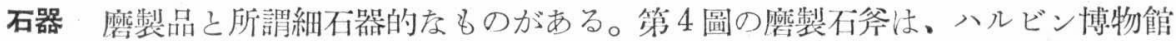

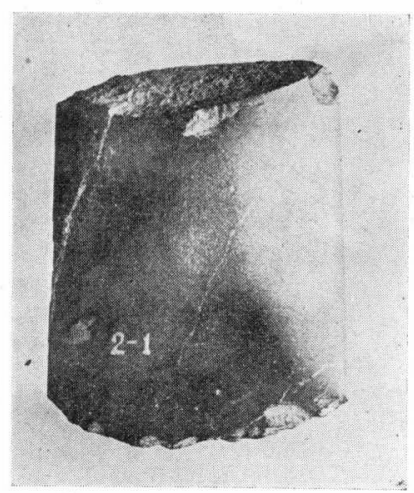

第 4 圖 の陳列品で B. V. SkvorTzov に探集されたもの。發 見地は老沙溝とあるが、恐らく同地を指すのではない かと思はれるので記戎した。之が殆に゙全長である事は その上端に磨研面が殘つて居るので解る。兩側線は研

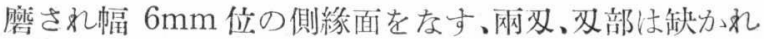
を部分が少くない。最厚部 $2.8 \mathrm{~cm}$ 位最大幅部約 $6.5 \mathrm{~cm}$ である。第 5 圖の 1 は、長さ約 $4.5 \mathrm{~cm}$ の打製品で 断面は略三伆形を呈する。2, 3 は打不鏃で可成りを精 品。4は Lame の殘片と思はれ、斷面は梯形であ る。 5 は判然をる retousche がない不詳品であるが、一打䌘下に生じたらしい畩面 を持つ。6 も不磪かなるのであるが、7 は矢印の部分に retousche と見える痕跡があ る。

同地に近接した遺跡としては、V.V. Ponosov *゙陶賴昭附近を豚の遺骨が新石器

* V. V. Ponosov: Agriculture and Cattle Breeding in North Manchuria, the Stone Age. Bulletin of the Institute of Scieientific Research, Manchoukuo. Vol. 1. No. 31937. 


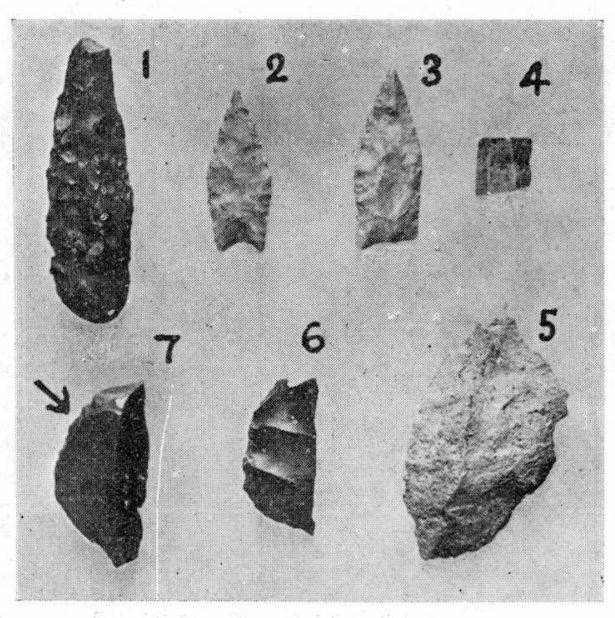

第 5 圖

時代遺物の間に發見された所として擧げ て居り、この松花汒站の名も馬の遺骨 (但不明)の發見の項に現れて居る。私も 調查の際淡水產貝類、器骨等を得た。然 し、之等と人工遺物との關係は今後の精 查俟つ可きであらら。

鬼に角、此地方が當時或種の文化の交 流進退を考へる上に、如何に興味あるか は誰の目にも明かであらう。細石器、所 謂鬲形土器其他を提示する同地の遺物相 は、夫等の年代的關係とそ斷言出來好之 は云へ、此邊の消息を物語る感がをいでもない。然し午ら、私共は現在のところ動摇 し易い分布論や、概說的な系統論の中の外安んじては居られない。寧ろより基礎的 なるフンドの研究に還らねばならない。

・上記の遺物が示す文化の位置、奎面的考察も、將來の精查後に俟たらと思ふ。最後 に此旅行に御厚情を賜つた本院副研究官石渡達六郎氏飞深謝の意を表する。

\section{NOTES ON THE PREHISTORIC ARTIFACTS FROM SUNGHUACHANG, NORTH MANCHURIA}

(ABSTRACT)

By

\section{NAOSHIGE OKUDA}

In the summer of 1938 , I had the oppotunity to investigating the prehistoric site in the vicnity of Sunghuachang station of the HsinkingHarbin line. The site was first investigatied by B. V. Skvortzov and next by A. A. Loukashkin. The artifacts which had been discovered by the auther and A. S. Loukashkin are as follows, a stone point ( 1 in fig. 5), stone arrowheads ( 2 and 3 in fig. 5), a fragment of a stone lame (4 in fig. 5), clay spindles (fig. 3) and a large quantity of pottery (figs. 1 and 2). 